UDC 616.2-057:669.3:622.831.3

DOI: 10.21668/health.risk/2019.2.11.eng

\title{
OCCUPATIONAL PATHOLOGY IN WORKERS EMPLOYED AT DEEP AND SURFACE MINING OF APATITE ORES IN THE KOLA ZAPOLYARYE
}

\author{
S.A. Syurin, S.A. Gorbanev \\ North-west Public Health Research Center, 4, 2nd Sovetskaya Str., Saint Petersburg, 191036, Russian Federation
}

Ore mining technologies are constantly developed and improved; nonetheless, most miners employed at apatite mines in Zapolyarny regions of the Kola Peninsula run higher risks of occupational diseases (OD). The research goal was to explore peculiarities related to OD occurrence in miners employed at deep and surface apatite mines. We examined data collected within social-hygienic monitoring activities in 2007-2017, the section "Working conditions and occupational morbidity"; the data were collected for the overall Murmansk region population, there were 470 patients with $O D$ and $749 O D$ cases revealed in the region over the selected time period. We detected that in case of deep mining $O D$ (first of all, in the musculoskeletal system) occurred at a younger age and after a shorter working period due to increased labor hardness (59.6\%). As regards surface mining, labor hardness and overall vibration were the basic etiologic factors there, and OD structure was characterized with considerable fractions of diseases in the musculoskeletal system (32.7\%) and vibration disease (hand-arm vibration syndrome, $31.8 \%$ ). OD number in one worker employed at deep mines was higher than in one worker employed at surface mining (1.68 \pm 0.07 and $1.49 \pm 0.5$, $p<0.02)$. Workers employed at deep mines run higher risks of deforming arthrosis $(R R=6.88 ; 95 \%$ CI 3.21-14.74; $\left.\chi^{2}=35.7 ; p<0.001\right)$ and forearms myofibrosis $\left(R R=8.11 ; 95 \% C I 1.92-34.1 ; \chi^{2}=11.8 ; p=0.0005\right)$; workers employed at surface mining run higher risks of vibration disease $\left(R R=1.40 ; 95 \%\right.$ CI $\left.1.08-1.80 ; \chi^{2}=6.69 ; p=0.009\right)$ and radiculopathy $\left(R R=1.47 ; 95 \% C I 1.12-1.93 ; \chi^{2}=7.61 ; p=0.006\right)$. Both occupational groups have to face unfavorable working conditions mostly due to technological processes and workplaces being out-of-date. We came to a conclusion that it was necessary to create programs aimed at prevention of occupational diseases in workers employed at apatite mines in the Arctic taking into account peculiarities related to hazardous occupational impacts and accompanying adverse factors associated with the chilling environment.

Key words: apatite ores, deep and surface mining, miners, occupational pathology, the Arctic, occupational diseases, musculoskeletal system diseases, vibration disease.

Khibiny apatite-nepheline ore mines that are located on the Cola Peninsula are among the richest in the world with their explored ore reserves exceeding 4 billion tons [1]. Ores have been mined there both in deep mines and on the surface since 30 ties last century and nowadays 26-28 million tons are extracted annually. On average, overall number of workers who directly deal with ore extraction under severe climatic conditions in this polar region amounts to 4-5 thousand people [2]. Technologies that are applied at mining and chemical enterprises are constantly developing but still most min- ers employed at apatite-nepheline ores in Polar Regions of the Cola Peninsula have to work under hazardous working conditions ${ }^{1}$ [3]. Overall and local vibration, labor hardness, noise, chilling microclimate at workplaces, dust and gas mixtures, work in forced and uncomfortable postures, as well as some other occupational factors lead to elevated risks of common and occupational diseases (OD) [4-7]. Natural and climatic conditions in the Far North are known to potentiate influences exerted by hazardous occupational factors on workers' health [8-10]. All the above mentioned indicates that it is relevant

(C) Syurin S.A., Gorbanev S.A., 2019

Sergey A. Syurin - Doctor of Medical Sciences, Chief researcher (e-mail: kola.reslab@mail.ru; tel.: +7(812)-7179783; ORCID: http://orcid.org/0000-0003-0275-0553).

Sergey A. Gorbanyov - Doctor of Medical Sciences, Director (e-mail: s-znc@mail.ru; tel.: +7(812)-7179783; ORCID: http://orcid.org/0000-00025840-4185).

\footnotetext{
${ }^{1}$ Prevention of occupational diseases in workers employed at mining and chemical enterprises in the Far North: Information and methodical letter. - Apatites, 2012. - 22 p.
} 
to reveal peculiarities related to health disorders and their prevention among miners who are exposed to hazardous occupational factors varying in their nature and intensity.

Our research goal was to examine peculiarities related to OD development in miners employed at apatite-nepheline mines and dealing with underground and surface mining in Polar Regions of the Cola Peninsula.

Data and methods. We examined social and hygienic monitoring data contained in "Working conditions and occupational incidence» section; the data were collected in Murmansk region over 2007-2017 and provided by the Rospotrebnadzor's Federal Center for Hygiene and Epidemiology.

We processed our research results with Microsoft Excel 2010 and IBM SPSS Statistics v.22 software. We determined Student's t-test for independent samplings, fitting criterion $\chi^{2}$, relative risk (RR), and $95 \%$ confidence interval $(95 \% \mathrm{CI})$. Numeric data were given as simple mean and standard error $(M \pm m)$. Critical significance of a zero hypothesis was considered to be 0.05 .

Results. We examined data on 470 miners employed at deep $(\mathrm{n}=256)$, and surface $(n=214)$ apatite-nepheline mines who had 749 occupational pathology cases diagnosed in them over 2007-2017.

Almost all miners $(98.9 \%)$ were males. Their average age at which occupational pathology was first detected in them amounted to $52.6 \pm 0.3$, and their working experience in mining industry was equal to $26.0 \pm 0.3$ лет. Age and working experience were higher among workers employed at surface mines $(p<0,001)$ than among those employed at deep ones (Table 1).

Given significant differences between deep and surface mining technologies $[2,11]$, occupations that examined workers had were beyond compare. As regards deep miners, OD were diagnosed in $48(18.8 \%)$ hole men, $39(15.2 \%)$ shaft men, $29(11.5 \%)$ drilling machine operators, $28(10.9 \%)$ load-haul-damper operators, 17 (6.6\%) underground miners, and
Table 1

Overall and occupational characteristics of miners employed at deep and surface apatite mines and suffering from occupational diseases

\begin{tabular}{|l|c|c|c|}
\hline \multicolumn{1}{|c|}{ Parameters } & $\begin{array}{c}\text { Deep } \\
\text { mines }\end{array}$ & $\begin{array}{c}\text { Surface } \\
\text { mines }\end{array}$ & Total \\
\hline $\begin{array}{l}\text { Sex: males } \\
\text { females }\end{array}$ & $\begin{array}{c}254 \\
(99.2 \%)\end{array}$ & $\begin{array}{c}211 \\
(98.6 \%)\end{array}$ & $\begin{array}{c}465 \\
(98.9 \%)\end{array}$ \\
\hline Age, years & $2(0.8 \%)$ & $3(1.4 \%)$ & $5(1.1 \%)$ \\
\hline $\begin{array}{l}\text { Work experience, } \\
\text { years }\end{array}$ & $24.6 \pm 0.5$ & $53.8 \pm 0.4^{*}$ & $52.6 \pm 0.3$ \\
\hline
\end{tabular}

Note: * means there are statistically significant discrepancies $(p<0.05)$ between miners employed at deep and surface mines.

15 (5.95) timbermen. Deep miners who had other occupations suffered from OD considerably less frequently.

As regards surface miners, OD were detected in $104(48.6 \%)$ mining track drivers, $43(20.1 \%)$ earthmover drivers, 26 (12.15) drilling machine operators, and 21 (9.8\%) bulldozer drivers. Workers with other occupations almost never suffered from OD.

Annually there were considerable changes in number of miners with first detected occupational pathologies over the examined periods, with both increases and decreases in it. In some cases, we even detected opposite dynamics in two workers' groups being compared. Workers employed at deep mines ran higher OD risks than those employed at surface mines in $2007 \quad(\mathrm{RR}=2.68 ; 95 \%$ CI $\left.1.08-6.66 ; \quad \chi^{2}=4.13 ; \mathrm{p}=0.042\right) ; \quad 2008$ $\left(R R=2.31 ; 95 \%\right.$ CI 1.04-5.15; $\chi^{2}=4.44$; $\mathrm{p}=0.035) ;$ and $2012(\mathrm{OP}=2.41 ; 95 \% \mathrm{CI}$ $\left.1.18-4.91 ; \quad \chi^{2}=5.17 ; \mathrm{p}=0.023\right)$. Only in 2015 workers employed at surface mines ran higher OD risks $(\mathrm{RR}=1.64 ; 95 \%$ CI 1.00 $\left.2.69 ; \chi^{2}=5.18 ; p=0.023\right)$. Over 11-year examined period, occupational incidence was the highest in 2011, 2014, and 2015. Overall, there was an ascending trend detected for first detected OD among miners over 2007-2015; but their number tended to decrease in 2016-2017 (Figure). 


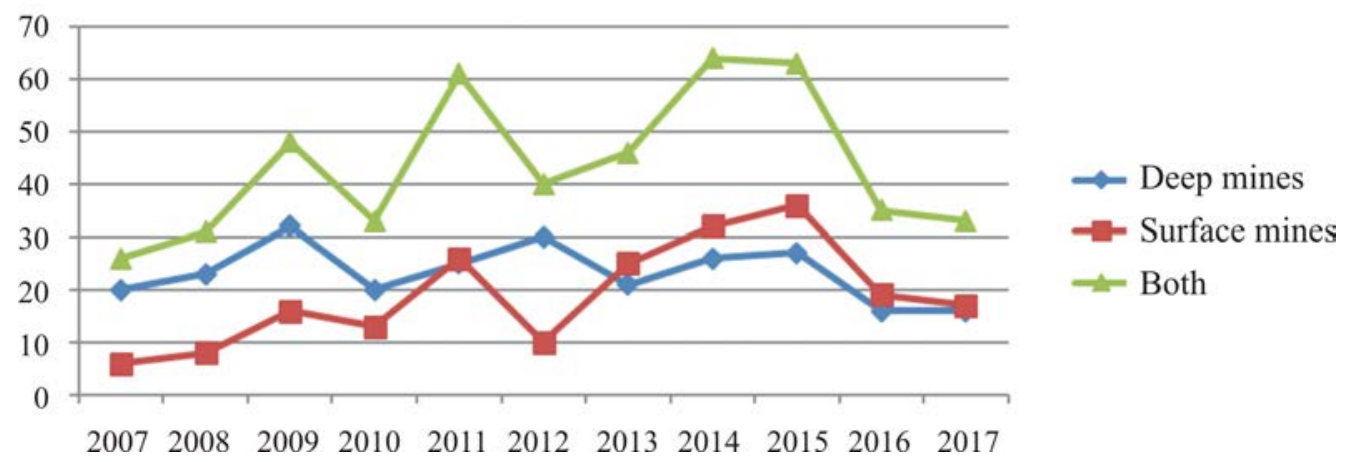

Figure. Annual number of miners with first detected occupational pathology

Number of OD cases was higher among deep miners than among those employed at surface mines $(\mathrm{p}<0.02)$. Structure of occupational pathology was quite similar in both groups. The first three rank places belonged to 1) musculoskeletal system diseases; 2) injuries, intoxications, and some other outcomes caused by external impacts; 3 ) nervous system diseases. Musculoskeletal system pathologies had bigger share in OD structure among deep miners than among those employed at surface mines $(p<0.001)$. Three most widely spread OD nosologies detected in deep miners included vibration disease, radiculopathy, and deforming arthrosis; as regards surface miners, they suffered from vibration disease, radiculopathy, and mono-polyneuropathy.

Workers employed at deep mines ran elevated risks of deforming arthrosis $(\mathrm{RR}=$ $=6.88 ; 95 \%$ CI 3.21-14.7; $\chi^{2}=35.7 ; \mathrm{p}<0.001$ ), and forearm myofibrosis ( $\mathrm{RR}=8.11 ; 95 \% \mathrm{CI}$ $\left.1.92-34.1 ; \chi^{2}=11.8 ; \mathrm{p}=0.0005\right)$; those employed at surface mines ran elevated risks of vibration disease $(\mathrm{RR}=1.40 ; 95 \% \mathrm{CI} 1.08-1.80$; $\left.\chi^{2}=6.69 ; \quad \mathrm{p}=0.009\right)$, and radiculopathy $\left(\mathrm{RR}=1.47 ; 95 \%\right.$ CI $1.12-1.93 ; \chi^{2}=7.61$; $\mathrm{p}=0.006)$.

There were six acute intoxications caused by carbon oxide and dioxide as well as by some other toxicants at deep mines. There were no such cases at surface mines. OD were more frequently detected as per regular medical check-ups results among deep miners $(\mathrm{p}<0.001)$ than among those employed at surface mines (Table 2).
There were significant discrepancies in hazard categories of working conditions that existed at deep and surface apatite mines. Working conditions at surface mines often belonged to 3.1 and 3.2 hazard category $(p<0.001) ; 3.3$ hazard category was rarer $(p<0.001)$; and we did not detect any working conditions that could be ranked as having 3.4 or 4 hazard category. At deep mines, there were several factors that caused occupational pathology occurrence such as toxic substances belonging to I-IV hazard category $(p<0.01)$, local vibration $(p<0.001)$, labor hardness with 3.1 hazard category or higher $(p<0.001)$; overall vibration was the most significant factor at surface mines $(\mathrm{p}<0.001)$.

Technological conditions that caused OD occurrence were similar in both groups of miners. The most significant technological factors were poorly developed technological processes, out-of-date organization of workplaces, machines, mechanisms, tools, accessories and equipment having constructive drawbacks (Table 3).

Discussion. Our research revealed that though technological processes were being developed at apatite mines in Polar Regions of the Cola Peninsula, it didn't lead to any substantial improvement of working conditions for miners; two thirds of them still had to work in a hazardous environment, with working conditions at their workplaces belonging to 3.2 hazard category. As it has always been, miners are among those workers 
Table 2

Occupational pathology among miners employed at apatite mines in the Arctic

\begin{tabular}{|c|c|c|c|}
\hline Parameters & Deep mines & Surface mines & Total \\
\hline Disease cases & 431 & 318 & 749 \\
\hline Diseases per 1 worker & $1.68 \pm 0.07$ & $1.49 \pm 0.05^{*}$ & $1.59 \pm 0.03$ \\
\hline \multicolumn{4}{|l|}{ Occupational nosologies: } \\
\hline Musculoskeletal system diseases & $207(48.0)$ & $104(32.7)^{*}$ & $311(41.5)$ \\
\hline $\begin{array}{l}\text { Injuries, intoxications, and some other outcomes caused by } \\
\text { external impacts }\end{array}$ & $97(27.0)$ & $101(31.8)$ & $198(26.4)$ \\
\hline Nervous system diseases & $66(15.3)$ & $58(18.2)$ & $124(16.6)$ \\
\hline Ear and mastoid diseases & $54(12.5)$ & $48(15.1)$ & $102(13.6)$ \\
\hline Respiratory organs diseases & $7(1.6)$ & $5(1.6)$ & $12(1.6)$ \\
\hline \multicolumn{4}{|l|}{ Most frequent diseases: } \\
\hline Vibration disease & $90(20.9)$ & $101(31.8)^{*}$ & $191(25.5)$ \\
\hline Radiculopathy & $77(17.9)$ & $91(28.6)^{*}$ & $168(22.4)$ \\
\hline Mono-polyneuropathy & $64(14.8)$ & $56(17.6)$ & $120(16.0)$ \\
\hline Sensorineural hearing loss (noise effects in inner ear) & $54(12.5)$ & $48(15.1)$ & $102(13.6)$ \\
\hline Deforming arthrosis & $75(17.4)$ & $7(2.2)^{*}$ & $82(10.9)$ \\
\hline Myofibrosis & $23(5.3)$ & $2(0.6)$ & $25(3.3)$ \\
\hline Chronic bronchitis & $6(1.4)$ & $3(0.9)$ & $9(1.2)$ \\
\hline \multicolumn{4}{|l|}{ Nature of a disease: } \\
\hline Acute & $6(1.4)$ & - & $6(0.8)$ \\
\hline Chronic & $425(98.6)$ & $318(100.0)$ & $743(99.2)$ \\
\hline \multicolumn{4}{|l|}{ Occupational diseases detection: } \\
\hline Medical check-up & $301(69.8)$ & $179(56.3)^{*}$ & $922(63.0)$ \\
\hline A patient applying for medical aid & $130(30.2)$ & $139(43.7)^{*}$ & $541(37.0)$ \\
\hline
\end{tabular}

Note: * means there are statistically significant discrepancies $(\mathrm{p}<0.05)$ between miners employed at deep and surface mines.

Table 3

Factors that caused occupational pathology occurrence among workers employed at apatite mines in the Arctic

\begin{tabular}{|l|c|c|c|}
\hline \multicolumn{1}{|c|}{ Parameters } & Deep mines & Surface mines & Total \\
\hline \multicolumn{1}{|c|}{ Working conditions categories: } & & & \\
\hline Hazard category 2 & $3(1.2)$ & $2(0.9)$ & $5(1.1)$ \\
\hline Hazard category 3.1 & $30(11.7)$ & $52(24.3)^{*}$ & $82(17.4)$ \\
\hline Hazard category 3.2 & $150(58.6)$ & $157(73.4)^{*}$ & $307(65.3)$ \\
\hline Hazard category 3.3 & $40(15.6)$ & $3(1.4)^{*}$ & $43(9.1)$ \\
\hline Hazard category 3.4 & $28(10.9)$ & $0 *$ & $28(6.0)$ \\
\hline Hazard category 4 & $5(1.9)$ & 0 & $5(1.2 \%)$ \\
\hline \multicolumn{1}{|c|}{ Factors causing occupational pathologies: } & & & \\
\hline Labor hardness (3.1 or higher hazard category) & $257(59.6)$ & $148(46.5)^{*}$ & $394(52.6)$ \\
\hline Overall vibration & $57(13.2)$ & $109(34.3)^{*}$ & $166(22.2)$ \\
\hline Noise & $54(12.5)$ & $48(15.1)$ & $102(13.6)$ \\
\hline Local vibration & $48(11.1)$ & $8(2.5)^{*}$ & $56(7.5)$ \\
\hline I-IV hazard category toxicants & $14(3.2)$ & $2(0.6)^{*}$ & $16(2.1)$ \\
\hline Fibrogenic aerosols & $1(0.2)$ & $3(0.9)$ & $4(0.5)$ \\
\hline
\end{tabular}


Occupational pathology in workers employed at deep and surface mining of apatite ores in the Kola Zapolyarye

\begin{tabular}{|l|c|c|c|}
\hline Technological conditions causing occupational pathologies: & & & \\
\hline Technological processes being poorly developed & $255(59.2)$ & $193(60.7)$ & $448(59.8)$ \\
\hline Out-of-date organization of workplaces & $117(27.1)$ & $86(27.0)$ & $203(27.1)$ \\
\hline $\begin{array}{l}\text { Machines, mechanisms, tools, accessories and equipment } \\
\text { having constructive drawbacks }\end{array}$ & $52(12.1)$ & $38(11.9)$ & $90(12.0)$ \\
\hline Technical regulations being violated & $5(1.2)$ & - & $5(0.7)$ \\
\hline Out-of-date sanitary-technical equipment & $2(0.5)$ & $1(0.3)$ & $3(0.2)$ \\
\hline Safety rules being violated & $2(0.5)$ & - & $2(0.3)$ \\
\hline
\end{tabular}

Note: * means there are statistically significant discrepancies $(\mathrm{p}<0.05)$ between miners employed at deep and surface mines.

who run elevated risks of occupational pathologies [11-13]. We detected that there were several significant factors causing occupational pathologies such as labor hardness, overall and local vibration, and noise. Poorly developed technological processes, out-of-date organization of workplaces and constructive drawbacks of machines, mechanisms, tools, accessories and equipment intensified negative influences exerted by risk factors on workers' health.

Musculoskeletal system diseases, just as before, took the first rank place in occupational pathology structure among miners employed at apatite mines $[7,14,15]$. The most widely spread nosologies in the category were radiculopathy, deforming arthrosis, and forearm myofibrosis. There were also such most widely spread pathologies as vibration disease and sensorineural hearing loss and it was quite consistent with the existing hazardous occupational factors.

Working conditions existing at deep mines were less favorable than those at surface ones. It can explain why OD occur among deep miners at younger age (51.6 \pm 0.5 against 53.8 $\pm 0.5, \quad \mathrm{p}<0.001)$ and after a shorter working experience period $(24.9 \pm 0.5$ against $27.4 \pm 0.5, \mathrm{p}<0.001)$. Labor hardness and local vibration caused high prevalence of musculoskeletal system diseases among workers employed at deep mines while workers employed at surface mines tended to suffer from vibration disease more frequently. We should also note that acute OD were detected only among workers employed at deep mines.
Since we performed our research in the Arctic region, we can well assume that adverse (chilling) microclimate at workplaces had its etiological significance $[9,16]$. Chilling, both overall and local, is well known to result in lower physical and mental working capacity, coordination disorders, elevated risks of health disorders and work injuries $[17,18]$. However, we didn't detect any OD caused by this factor. Probably, impacts exerted by exposure to cold on miners' bodies were not fully explored due to meteorological defects in control and surveillance activities. Another issue is serious differences (both decreases and increases) in number of OD cases annually detected in workers employed at deep and surface apatite mines. Inconsistence existing in cause-and-effect relations between working conditions and workers' health make us assume there are influences exerted by other factors such as low-quality medical check-ups, OD number being regulated by administrative personnel, etc. [19, 20].

Conclusion. Programs aimed at preventing occupational pathology among workers employed at apatite mines in the Arctic should be developed taking into account peculiarities of impacts exerted by adverse occupational factors. It is vital to make labor processes easier both for deep and surface miners and to decrease overall vibration at surface mines. Technical measures aimed at preventing health disorders should primarily involve technological processes improvement and better workplace organization, elimination of constructive defects in machinery and other equip- 
ment, as these factors cause more than $85 \%$ occupational pathology cases detected among miners employed at apatite mines in Cola Polar Regions. It is also necessary to improve techniques for assessing influences exerted on workers' health by chilling microclimate at workplaces as it can enhance and modify effects produced by adverse occupational factors.

Funding. The research was not granted any sponsor support.

Conflict of interests. The authors state there is no any conflict of interests.

\section{References}

1. Geologicheskaya entsiklopediya. Khibinskie mestorozhdeniya [Geological encyclopedia. Khibiny deposits]. Available at: https://www.dic.academic.ru/dic.nsf/enc_geolog/5395 (02.12.2018) (in Russian).

2. Integrated report 2017. Growth. Efficiency. Value. Phosagro. Available at: https://www.phosagro.ru (02.12.2018) (in Russian).

3. Skripal' B.A. Occupational morbidity, its features on enterprises of mining and chemical complex in Kola Polar region. Ekologiya cheloveka, 2008, no. 10, pp. 26-30 (in Russian).

4. Karnachev I.P., Golovin K.A., Panarin V.M. The industrial occupational safety level on the basis of occurrence rate of industrial injuries at the Murmansk region mining enterprises. Izvestiya Tul'skogo gosudarstvennogo universiteta. Estestvennye nauki, 2012, vol. 1, no. 2, pp. 95-100 (in Russian).

5. Gorbanev S.A., Syurin S.A. Influence of working conditions and duration of work on health of northern miners. Meditsina truda i promyshlennaya ekologiya, 2018, no. 5, pp. 44-49 (in Russian).

6. Øvrum A., Skandfer M., Nikanov A., Syurin S., Khokhlov T. Hand-arm vibration syndrome in apatite miners in Northwest Russia. The $4^{\text {th }}$ International Conference on Whole-body Vibration Injuries. Montreal, Canada, 2009, pp. 105-106.

7. Burström L., Aminoff A., Björ B., Mänttäri S., Nilsson T., Pettersson H. [et al.]. Musculoskeletal symptoms and exposure to whole-body vibration among open-pit mine workers in the Arctic. International Journal of Occupational Medicine and Environmental Health, 2017, vol. 30, no. 4, pp. 553-564.

8. Chashchin V.P., Dedenko I.I. Trud izdorov'e cheloveka na Severe [Labor and human health in the North]. Murmansk, Knizhnoe izdatel'stvo Publ., 1990, 140 p. (in Russian).

9. Khasnulin V.I., Khasnulin P.V. Modern concepts of the mechanisms forming northern stress in humans in high latitudes. Ekologiya cheloveka, 2012, no. 1, pp. 4-11 (in Russian).

10. Burström L., Nilsson T., Walström J. Combined exposure to vibration and cold. Barents Newsletters on Occupational Health and Safety, 2015, vol. 18, no. 1, pp. 17-18.

11. MineHealth 2012-2014: Guidebook on cold, vibration, airborne exposures and socioeconomic influences in open pit mining. In: A. Paloste, A. Rönkkö eds. Available at: http:// minehealth.eu/final-report/ (16.12.2016).

12. Kuptsov V.N., Skripal' B.A., Efimova T.I., Kudryashov A.N. Rasprostranennost' khronicheskoi patologii na predpriyatiyakh gorno-khimicheskogo kompleksa Kol'skogo Zapolyar'ya [Prevalence of the chronic pathology on the mining-and-chemical industry of Kola Arctic Circle]. Ekologiya i okhrana zdorov'ya rabochikh promyshlennykh predpriyatii v Barents-regione: materialy simpoziuma s mezhdunarodnym uchastiem. Kirovsk, 2008, pp. 8-10 (in Russian).

13. Syurin S.A., Chashchin V.P., Shilov V.V. Occupational health hazards arising during mining and processing of apatite ores in Kola high north. Ekologiya cheloveka, 2015, no. 8, pp. 10-15 (in Russian).

14. Syurin S.A., Burakova O.A. Features of general and occupational pathology in miners of apatite mines in Far North Kola Research Laboratory for Occupational Health. Meditsina truda $i$ promyshlennaya ekologiya, 2012, no. 3, pp. 15-19 (in Russian).

15. Skripal' B.A. Health state and morbidity of underground mines in mining chemical enterprise in Arctic area of Russian Federation. Meditsina truda i promyshlennaya ekologiya, 2016, no. 6, pp. 23-26 (in Russian). 
16.Rintamäki H., Jussila K., Rissanen S., Oksa J., Mänttäri S. Work in Arctic open-pit mines: Thermal responses and cold protection. Barents Newsletters on Occupational Health and Safety, 2015, vol. 18, no. 1, pp. 6-8.

17. Anttonen H., Pekkarinen A., Niskanen J. Safety at work in cold environments and prevention of cold stress. Industrial Health, 2009, vol. 47, no. 3, pp. 254-261.

18. Kue T., Mäkinen T. The health of Arctic populations: Does cold matter? American Journal of Human Biology, 2010, no. 22, pp. 129-133.

19. Babanov S.A., Budash D.S., Baikova A.G., Baraeva R.A. Periodic medical examinations and occupational selection in industrial medicine. Zdorov'e naseleniya i sreda obitaniya, 2014, no. 8, pp. 18-21 (in Russian).

20. Khoruzhaya O.G., Gorblyanskii Yu.Yu., Piktushanskaya T.E. Indicators and criteria of the assessment of quality of medical examinations of workers. Meditsina truda i promyshlennaya ekologiya, 2015, no. 2, pp. 21-26 (in Russian).

Syurin S.A., Gorbanyov S.A. Occupational pathology in workers employed at deep and surface mining of apatite ores in the Kola Zapolyarye. Health Risk Analysis, 2019, no. 2, pp. 101-107. DOI: 10.21668/health.risk/2019.2.11.eng

Received: 21.12 .2018

Accepted: 25.05.2019

Published: 30.06.2019 